\title{
CURVATURE ANALYSIS FOR ASYMMETRICAL MULTI-LAYER COMPOSITE
}

\section{LOKŠŅU AR NESIMETRISKU, DAUDZSLĀṆAINU STRUKTŪRU LIEKUMU APRĒĶINS}

Janis Sliseris, Riga Technical University, 1 Kalķu Street, Riga LV-1658, Latvia, student, without degree, Janis.sliseris@gmail.com

Karlis Rocens, Riga Technical University, 1 Kalķu Street, Riga LV-1658, Latvia, professor, Dr.habil.sc.ing., rocensk@latnet.lv 
Keywords: curvature interaction; orthogonal structure; moisture influence on elastic characteristic;

\section{Introduction}

Composite with multilayer asymmetric structure gets curvature while it is conditioning in temperature-moisture changing process. Asymmetric structure is gained by orientating layers in different directions. There are many factors that affect curvature of the sheet. The most important are sheets geometrical properties- thickness and orientation of layers, temperature-moisture changing process. Layers are made from orthotropic material with various thermal or moisture expansion coefficients in different directions. In case of wood composite, moisture changing process affects curvature more then temperature changing process, therefore moisture changing process is analyzed in details.

There are other factors that affect curvature. If the sheet gets relative large curvature then it is important to take into account geometrical nonlinearity. It means that curvature in one direction depends on curvature in orthogonal direction. This effect is called curvature interaction. If we take into account this effect than values of curvatures are decreased.

During the process of temperature-moisture changing, changes also values of material elastic characteristics.

\section{Theoretical background}

\subsection{Stress-strain relationship in thin plate}

Curvature calculation could be done by using algorithm, described in $[1,2,3]$.This analytical method is based on Kirchoff-Love thin plate theory. This theory is based on the general Hooke law

$$
\left[\sigma_{i}\right]=\left[C_{i j}\right] \cdot\left[\varepsilon_{i}\right],
$$

where $i, j=1 . .6 ;\left[\sigma_{i}\right]-$ stress matrix; $\left[C_{i j}\right]$ - stiffness matrix; $\left[\varepsilon_{i}\right]-$ strain matrix.

The general Hooke Law could be changed using Kirchoff hypothesis of thin plate and technical expressions. It reduces to the following expression

$$
\left[\begin{array}{c}
\sigma_{1} \\
\sigma_{2} \\
\tau_{12}
\end{array}\right]=\left[\begin{array}{ccc}
\frac{E_{1}}{1-v_{12} v_{21}} & \frac{v_{21} E_{1}}{1-v_{12} v_{21}} & 0 \\
\frac{v_{12} E_{2}}{1-v_{12} v_{21}} & \frac{E_{2}}{1-v_{12} v_{21}} & 0 \\
0 & 0 & G_{12}
\end{array}\right] \cdot\left[\begin{array}{c}
\varepsilon_{1} \\
\varepsilon_{2} \\
\gamma_{12}
\end{array}\right],
$$

where $E_{1} ; E_{2}$ - modulus of elasticity in direction 1 and $2 ; v_{12} ; v_{21}$-Poisson ratio; $G_{12}$-shear modulus.

In expression (2) is used layer local coordinate system 1-2-Z. In case of composite sheet, stress and strain have to be calculated in global coordinate system X-Y-Z. The stress matrix is calculated in another coordinate system using transformed stiffness matrix 


$$
\left[\begin{array}{c}
\sigma_{X} \\
\sigma_{Y} \\
\tau_{X Y}
\end{array}\right]=\left[\overline{Q_{i j}}\right] \cdot\left[\begin{array}{c}
\varepsilon_{X} \\
\varepsilon_{Y} \\
\gamma_{X Y}
\end{array}\right],
$$

where $i, j=1,2,3 ;\left[\overline{Q_{i j}}\right]$-transformed stiffness matrix.

Geometrical relationship between mid surface deflation $w_{0}$ and strain $\varepsilon_{i}$ and horizontal displacement $u_{0}$ could be built up

$$
\left\{\begin{array}{l}
\varepsilon_{X}=\frac{\partial u_{0}}{\partial x}-z \frac{\partial^{2} w_{0}}{\partial x^{2}} \\
\varepsilon_{Y}=\frac{\partial v_{0}}{\partial y}-z \frac{\partial^{2} w_{0}}{\partial y^{2}} \\
\gamma_{X Y}=\frac{\partial u_{0}}{\partial y}+\frac{\partial v_{0}}{\partial x}-2 z \frac{\partial^{2} w_{0}}{\partial y \partial x}
\end{array},\right.
$$

where $w_{0}$ - function of plate mid surface deflection, depending on coordinate $\mathrm{x}$ and $\mathrm{y} ; u_{0}-$ function of plate mid surface horizontal displacement, depending on coordinate $\mathrm{x}$ and $\mathrm{y}$; $\mathrm{z}$ - coordinate on axis Z- orthogonal to plate surface.

From system of equation (4) separate curvature matrix

$$
\left[\begin{array}{c}
k_{X}^{0} \\
k_{Y}^{0} \\
k_{X Y}^{0}
\end{array}\right]=-\left[\begin{array}{c}
\frac{\partial^{2} w_{0}}{\partial x^{2}} \\
\frac{\partial^{2} w_{0}}{\partial y^{2}} \\
\frac{\partial^{2} w_{0}}{\partial y \partial x}
\end{array}\right],
$$

where $k_{X}^{0}, k_{Y}^{0}$ - curvature of mid-surface relative to axis $\mathrm{x}$ and $\mathrm{y} ; k_{X Y}^{0}$-yearn angle of mid-surface.

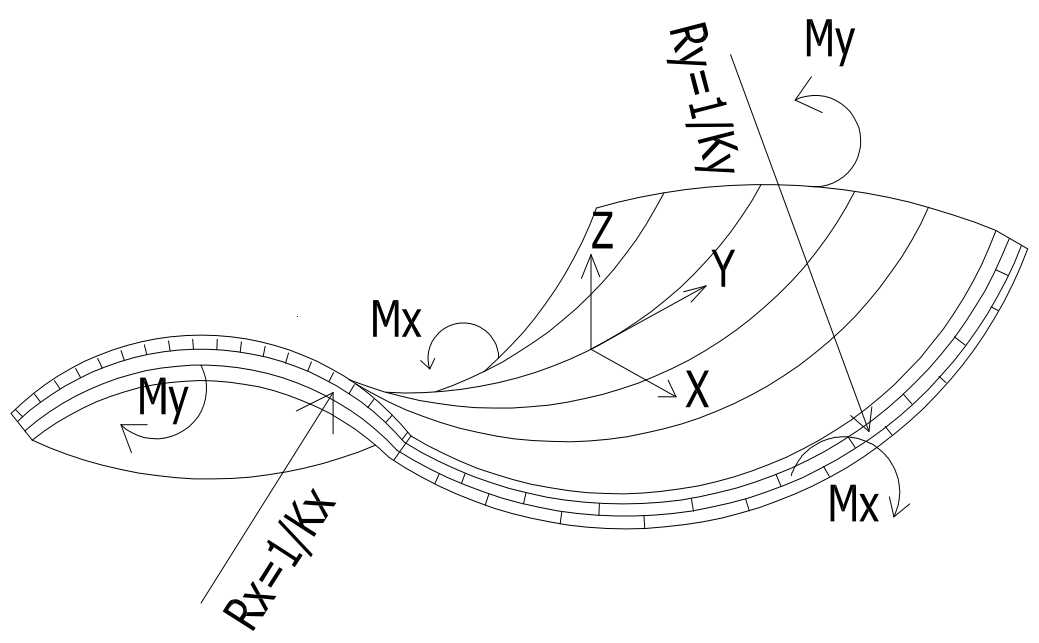

Fig 1. Geometric interpretation of curvature.

Geometrical equations (5) and physical equations (3) could be jointed together 


$$
\left[\sigma_{u}\right]=\left[\bar{Q}_{i j}\right] \cdot\left[\left[\varepsilon_{u}^{0}\right]+z\left[k_{u}^{0}\right]\right]
$$

where $u=x, y, x y ;\left[\varepsilon_{u}^{0}\right]$ - mid-surface strain matrix.

\subsection{Equations for multilayered composite}

For simplify deformation model it is helpful to replace stress with equal system of moment and force that affects per unit length.

Force matrix could be calculated by summing stress matrix throughout sheets thickness

$$
\left[\begin{array}{c}
N_{X}^{0} \\
N_{Y}^{0} \\
N_{X Y}^{0}
\end{array}\right]=\int_{\frac{-h}{2}}^{\frac{h}{2}}\left[\begin{array}{c}
\sigma_{X} \\
\sigma_{Y} \\
\tau_{X Y}
\end{array}\right] d z=\sum_{k=1}^{n} \int_{z_{k-1}}^{z_{k}}\left[\begin{array}{c}
\sigma_{X} \\
\sigma_{Y} \\
\tau_{X Y}
\end{array}\right]_{k} d z
$$

where $N_{X}^{0} ; N_{Y}^{0}$ - axial force in direction $\mathrm{x}$ and $\mathrm{y}$, acting on mid-surface; $N_{X Y}^{0}$ - yearn force in direction $\mathrm{xy} ; \mathrm{h}$ - thickness of sheet; $\mathrm{N}$ - number of layers in sheet; $z_{k} ; z_{k-1}$-layer $k$ bottom and top coordinate on axis $\mathrm{Z}$.

Moment matrix is calculated by summing stress matrix multiplication to coordinate $z$ throughout thickness of sheet

$$
\left[\begin{array}{c}
M_{X}^{0} \\
M_{Y}^{0} \\
M_{X Y}^{0}
\end{array}\right]=\int_{\frac{-h}{2}}^{\frac{h}{2}}\left[\begin{array}{c}
\sigma_{X} \\
\sigma_{Y} \\
\tau_{X Y}
\end{array}\right] z d z=\sum_{k=1}^{N} \int_{z_{k-1}}^{z_{k}}\left[\begin{array}{c}
\sigma_{X} \\
\sigma_{Y} \\
\tau_{X Y}
\end{array}\right]_{k} z d z
$$

where $M_{X}^{0} ; M_{Y}^{0}-$ moment acting in direction $\mathrm{x}$ and $\mathrm{y}$ on mid-surface; $M_{X Y}^{0}$ - yearn moment acting in direction xy on mid-surface.

After integrating equation (7) and (8) could rewrite force and moment expresions using matrix $A, B, D$

where $i, j=1,2,3$;

$$
\begin{aligned}
& {\left[\begin{array}{c}
N_{X}^{0} \\
N_{Y}^{0} \\
N_{X Y}^{0}
\end{array}\right]=\left[A_{i j}\right] \cdot\left[\begin{array}{c}
\varepsilon_{x}^{0} \\
\varepsilon_{x}^{0} \\
\gamma_{x y}^{0}
\end{array}\right]+\left[B_{i j}\right] \cdot\left[\begin{array}{c}
k_{X}^{0} \\
k_{Y}^{0} \\
k_{X Y}^{0}
\end{array}\right]} \\
& {\left[\begin{array}{c}
M_{X}^{0} \\
M_{Y}^{0} \\
M_{X Y}^{0}
\end{array}\right]=\left[B_{i j}\right] \cdot\left[\begin{array}{c}
\varepsilon_{x}^{0} \\
\varepsilon_{x}^{0} \\
\gamma_{x y}^{0}
\end{array}\right]+\left[D_{i j}\right] \cdot\left[\begin{array}{c}
k_{X}^{0} \\
k_{Y}^{0} \\
k_{X Y}^{0}
\end{array}\right]}
\end{aligned}
$$

Matrix $A, B, D$ coefficients is calculated using following equations

$$
\begin{aligned}
& A_{i j}=\sum_{k=1}^{N}\left(\overline{Q_{i j}}\right)_{k}\left(z_{k}-z_{k-1}\right) \\
& B_{i j}=\frac{1}{2} \sum_{k=1}^{N}\left(\overline{Q_{i j}}\right)_{k}\left(z_{k}^{2}-z_{k-1}^{2}\right) \\
& D_{i j}=\frac{1}{3} \sum_{k=1}^{N}\left(\overline{Q_{i j}}\right)_{k}\left(z_{k}^{3}-z_{k-1}^{3}\right)
\end{aligned}
$$


In the nature there are many actions on sheet, one of them are moisture. Force and moment that arise form moisture changing process is calculated using equations

$$
\begin{aligned}
& {\left[N_{u}^{0}\right]=\sum_{k=1}^{n}\left[\overline{Q_{i j}}\right]_{k}\left[\beta_{u}\right] \Delta W\left(z_{k}-z_{k-1}\right)} \\
& {\left[M_{u}^{0}\right]=\frac{1}{2} \sum_{k=1}^{n}\left[\overline{Q_{i j}}\right]_{k}\left[\beta_{u}\right] \Delta W\left(z_{k}^{2}-z_{k-1}{ }^{2}\right)}
\end{aligned}
$$

where $\left[\beta_{u}\right]-$ matrix of material moisture expansion coefficients; $\Delta W$-total moisture increment or decrement.

After joining equations (9), (10), (12) we have matrix expression which gives sheets deformation and curvature matrix.

$$
\left[\begin{array}{l}
{\left[\varepsilon_{u}^{0}\right]} \\
{\left[k_{u}^{0}\right]}
\end{array}\right]=\left[\begin{array}{ll}
{\left[A_{i j}\right]} & {\left[B_{i j}\right]} \\
{\left[B_{i j}\right]} & {\left[D_{i j}\right]}
\end{array}\right]^{-1}\left[\begin{array}{c}
{\left[N_{u}^{0}\right]} \\
{\left[M_{u}^{0}\right]}
\end{array}\right]
$$

\section{Improved algorithm}

The most important failures of currently used analytical method [1,2,3] are:

- It doesn't take into account material elastic characteristic change in process of moisture change.

- It doesn't take into account curvature interaction- geometrical nonlinearity.

The developed model consists of an algorithm that is based on a single loop with $n$ iterations. That single loop divides the total moisture increment/decrement- $\Delta W$ to $n$ smaller increments/decrements $d W$ of the moisture. In each iteration there are calculated a new material elastic characteristics, which are dependent on moisture. Equation (13) is replaced with the following equation

$$
\left[\begin{array}{l}
{\left[\varepsilon_{u}^{0}(w)\right]} \\
{\left[k_{u}^{0}(w)\right]}
\end{array}\right]_{l}=\left[\begin{array}{ll}
{\left[A_{i j}(w)\right]} & {\left[B_{i j}(w)\right]} \\
{\left[B_{i j}(w)\right]} & {\left[D_{i j}(w)\right]}
\end{array}\right]_{l}^{-1}\left[\begin{array}{l}
{\left[N_{u}^{0}(w)\right]} \\
{\left[M_{u}^{0}(w)\right]}
\end{array}\right]_{l}
$$

where $u=x, y, x y ; w$ - moisture of sheet throughout thickness; $l$ - number of iteration.

In the iteration number $l$ there is calculated deformation and curvature matrix that arise from moisture increment/decrement- $d W$. Deformations and yearn are summed together in the total deformation and yearn matrix, without any correction

$$
\left[\begin{array}{c}
{\left[\varepsilon_{u}^{0}(w)\right]} \\
k_{X Y}^{0}(w)
\end{array}\right]=\sum_{l=1}^{n}\left[\begin{array}{l}
{\left[\varepsilon_{u}^{0}(w)\right]} \\
k_{X Y}^{0}(w)
\end{array}\right]_{l}
$$

In each iteration values of curvature $k_{X}^{0}(w)$ and $k_{Y}^{0}(w)$ are corrected, according to the expression (16). After making curvature correction they are summed together in the total curvature matrix

$$
\left[\begin{array}{c}
k_{X}^{0}(w) \\
k_{Y}^{0}(w)
\end{array}\right]=\sum_{l=1}^{n}\left[\begin{array}{c}
k_{X}^{0}(w) \cdot \frac{I_{0, y}}{I_{l, y}} \\
k_{Y}^{0}(w) \cdot \frac{I_{0, x}}{I_{l, x}}
\end{array}\right]_{l}
$$


where $I_{0, x}, I_{0, y}$ - moment of inertia for flat plate relative to axis $\mathrm{x}$ and $\mathrm{y}$, it is calculated using expression (17); $I_{l, x}, I_{l, y}$ - moment of inertia for $l$ step curved plate relative to axis $\mathrm{x}$ and $\mathrm{y}$, it is calculated using expression (18); n- number of iteration.

$$
I_{0 u}=\frac{a \cdot h^{3}}{12}
$$

where $u=x, y$; $a$ - length of sheet edge in direction $u$;

$$
I_{l, u}=\frac{a^{3}}{8} h\left(\frac{4 R_{u}{ }^{2}}{a}+\frac{\sin \left(\frac{2 R_{u}}{a}\right) \cos \left(\frac{2 R_{u}}{a}\right)}{\frac{8 R_{u}{ }^{3}}{a^{3}}}-\frac{2 \sin ^{2}\left(\frac{2 R_{u}}{a}\right)}{\frac{16 R_{u}{ }^{4}}{a^{4}}}\right)+\frac{a \cdot h^{3}}{12}
$$

where $u=x, y ; R_{u}$-radius of curvature in direction $u$, geometrical interpretation shown in Figure 1 .

Using this algorithm curvature analysis is done taking into account physical and geometrical nonlinearity.

In this algorithm very important factor is length of sheets edge. Previously used algorithm $[1,2,3]$ didn't take into account this geometrical factor.

Algorithm is implemented in the computer program Matlab R2008a.

\section{Numerical experiments}

The improved algorithm was used to calculate square-shaped $\left(I_{0, X}=I_{0, Y}\right) 4$ layered sheets with variable $I_{0, u}(u=X, Y)$, made from birch-tree (elastic characteristics are taken from [4]), first two layers (54.5\% of total wood) are orientated in direction $y$, others (45.5\%) orthogonally. In all cases the total area of cross section is $275 \mathrm{~cm}^{2}$. Numerical experiments were made by changing $I_{0, u}$ and final wood moisture- $\mathrm{W}_{\text {fin }}$, keeping constant total moisture increment $4 \%$. Experiment results shown in Figure 2. and Figure 3.

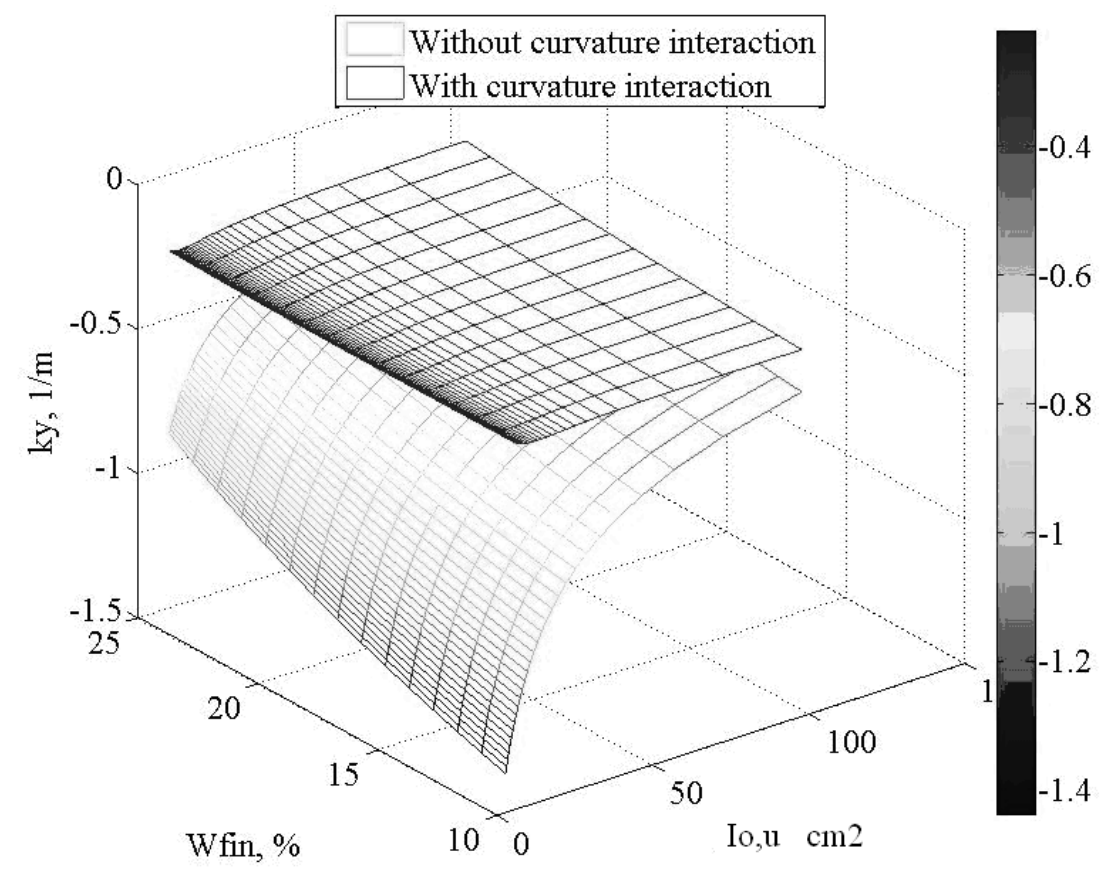

Fig 2. The dominant curvature dependence of sheet geometrical properties and moisture condition 


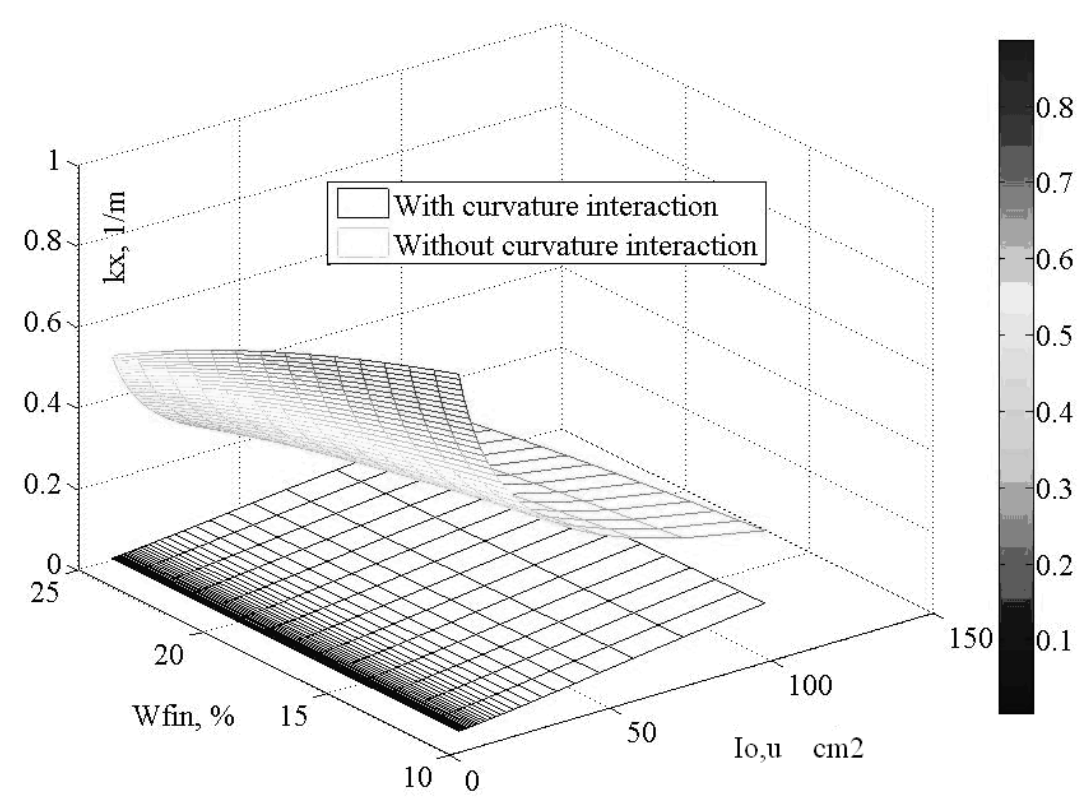

Fig 3. The secondary curvature dependence from sheet geometrical properties and moisture condition

There was made another four experiments using finite element method (ANSYS v.10). Experiments were made with the square-shaped sheet that is made from birch tree (elastic characteristics taken form [4]) with four layer structure. The first two layers are orientated in direction $\mathrm{X}$ with thickness $1.5 \mathrm{~mm}$, third and fourth layer are orientated orthogonally-in direction $\mathrm{Y}$. The third layer thickness is $1.5 \mathrm{~mm}$, the fourth layer thickness is $1 \mathrm{~mm}$.

Each layer where divided into finite elements- Solid 45. Layers were modeled as an elastic orthotropic material. Elastic characteristics where defined in two moisture levels- $10 \%$ and $6 \%$. Linear function was used to approximate elastic characteristic change in moisture changing process. Analysis of curvature was made using large deformation effect (LDE) and without using it. Experiment where made for sheets with two different length of edge $a-50 \mathrm{~mm}$ and $200 \mathrm{~mm}$. Results are shown into Table 1.

Table 1

Experiment results with FEM

\begin{tabular}{|c|c|c|c|c|}
\hline \multirow{2}{*}{$\begin{array}{c}\text { a, } \\
\mathrm{mm}\end{array}$} & \multicolumn{4}{|c|}{ Ansys v.10 } \\
\cline { 2 - 5 } & \multicolumn{2}{|c|}{$\begin{array}{c}\text { Without using } \\
\text { LDE }\end{array}$} & \multicolumn{2}{c|}{ Using LDE } \\
\hline & $\mathrm{kx}, 1 / \mathrm{m}$ & $\mathrm{ky}, 1 / \mathrm{m}$ & $\begin{array}{c}\mathrm{kx}, \\
1 / \mathrm{m}\end{array}$ & $\mathrm{ky}, 1 / \mathrm{m}$ \\
\hline 50 & 1.1563 & -1.9379 & 1.0717 & -1.8828 \\
\hline 200 & 1.1780 & -1.4316 & 0.1601 & -1.2255 \\
\hline
\end{tabular}

\section{Discussion of results}

Numerical experiments showed that using curvature interaction effect curvature is smaller than without using curvature interaction effect. The secondary curvature is reduced more than the dominant curvature.

The effect of curvature interaction is less important if the ratio of $a$ and $h$ is smaller, where $a-$ length of sheet edge, and $h$ - thickness.

Equal sheets where calculated using analytical method and using computer program ANSYS v.10, that is based on finite element method (FEM). The results showed that result difference is significant. For previously described sheets the difference is $22 \%$ in case of ignoring large deformation effect, but in case of large deformation effect the result difference is $36 \%$. 


\section{References}

1. Reissner E., Stavsky I. Bending and stretching of certain types of heterogeneous aelotropic elastic plates.- Trans. ASME. Ser. E, 1961, vol. 28, N 3, pp. 402-408.

2. Rocens K, Šteiners K. Stiffness and ductability analysis for unbalanced monoclinic composite.Mechanic of polymer, 1976, vol. 6 (in Russian).

3. Skudra A.M, Skudra A.A. Introduction in mechanic of composite material. Riga, RTU, 2002 (in Latvian).

4. Pereligin A.M., Ugolev B.N. Wood maintenance, 1971, Wood industry, Moscow (in Russian).

\section{Šliseris J., Rocēns K. Lokšṇu ar nesimetrisku, daudzslāṇainu struktūru liekuma aprēḳins}

Viena no iespējām samazināt materiāla patēriņu pārsegumos ir plakanu plātņu aizstāšana ar izliektām vai izliekti- ieliektām plātnēm (čaulām). Šāds risinājums ir üpaši izdevīgs slānainu koksnes kompozītmateriāalu lokšnnu izmantošanas gadījumā pie noteikuma, ka izliektās vai izliekti-ieliektās loksnes tiek izgatavotas plaši lietotās daudzstāù̃gās saplākšnna līmēšanas presēes ar paralēliem plauktiem. Lokšnnu izliektā vai izliekti ieliektā forma tiek panākta izvēloties slānnus ar nepieciešamajām fizikāli mehāniskajām īpašš̄bām, ǵeometriskiem izmēriem, orientāciju, mērkstiecīgi izvietojot tos un izveidojot strukturāli nesimetrisku pret loksnes vidusplakni materiālu, kuř̌s pēc kondicionēšanas noteiktos mitruma-temperatūras apstākḷos izliecas saskaṇā ar kompozītu prognozēto formu.

\section{Sliseris J., Rocens K. Curvature analysis for asymmetrical multi-layer composite}

One possibility to reduce material consumption in bent construction is flat plate replacement with curved or saddle shaped plate (shell). This solution is beneficial in case of plywood sheet, provided that curved or saddle shaped plates are made in widely used multilevel plywood presses with parallel shelves. Curvature is gained by using layers with required physical properties, geometric dimensions, orientation, creating structurally asymmetrical material, relative to mid-surface. While it is conditioning in different moisture-temperature conditions, it gains projected shape.

\section{Слисерис Я., Роценс К. Кривизна анализ асимметричный многослойные композит}

Одна из возможностей для снижения потребления материала в строительстве согнута плоская пластина с заменой седла или изогнутые формы пластины (оболочки). Это решение выгодно в случае листа фанеры, при условии, что изогнутые или в форме седла плиты изготавливаются в широко используется многоуровневая фанеры прессов с параллельными полками. Кривизна достигается с помощью слоев с требуемыми физическими свойствами, геометрические размеры, ориентация, создание структурно асимметричная материала, по отношению к середине поверхности. Несмотря на то, что кондиционер влаги в различных температурных условиях, то прогнозируемые прибыли форму. 